口盗料

\title{
グラスウールを用いた空気洗浄器の性能 (その1)*
}

(熱交換器としての性能)

田島収**司馬康男***. 堀正***

\section{1. はしがき}

ガラス絵維を充填物として用いた空気洗浄器（キャビ ラリ・エアウォッシャー)は, 水と空気とが密接に接触 するので, 水一空気の直接接触熱交換器として用いた場 合の性能す優れている。

この型式の実験装置を使って, 冷水和よび温水を送っ た場合の性能を調へたので，つきにその結果の一部を紹 介する。

\section{2. 実験薮通およひ実験方法}

装置は Fig.1の上うに全体をトタン板て作り，その

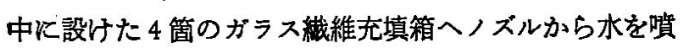
藩した。空気と水の流れとは，ここでは並流として用い た。貲蓩水は充填物面へ平均供散布するのが目的である ので，その压力はあまり高い必要はなく，1 kg/ $/ \mathrm{cm}^{2}$ 程 度でも十分である。装直の下部の水溜めへ詝った水は， 別济設けてある眝水槽（兼加熱槽・冾却槽）へ戻り，ボ ンプで再びノズルへ送られる。

(1) グラスウール充填物

Fig. 2 のよう飞, 直 径約 $0.2 \mathrm{~mm}$, 長さ約 $180 \mathrm{~mm}$ のグラスウール多数を充 填箱 $(50 \times 50 \times 20 \mathrm{~cm})$ 内へ縰方向に並べて詰めたすの である。合成樹脂接着剂により各栱維を軽く接着して動 かぬ上ラKしてある。その見哄けの比重量は約 $52 \mathrm{~kg} / \mathrm{m}^{3}$ のものを用いたが，ぞの程度の比重量のるのが最適であ るかは今後の問題である。この充填物の入った箱 4 箇を 水平汶対して的 $35^{\circ}$ の㑯きに並へて取付けた。したがっ て大部分のガラスゥールは水平に対して約 $55^{\circ}$ 傾いて並
んでいることになる。

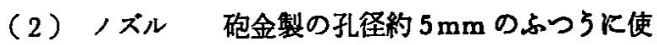
われている旋回流式のるのを用いた。へッダーの上段に 9 箇と下段に 10 籄で合計 19 籄取付けて山る。

（3）給水装㯰 1"1/2 径の遠心ホホンプを 2 馬力の モーターて駆動し，ズル入口の水圧を $0.5 \sim 1.0 \mathrm{~kg} /$ $\mathrm{cm}^{2}$ の問の任意の圧力に保つ上らにハハルブで調節した。 ただし， $0.5 \mathrm{~kg} / \mathrm{cm}^{2}$ のときは隫蓩がやや乱れるので, $0.7 \mathrm{~kg} / \mathrm{cm}^{2}$ またはそれ以上の圧力て噴第した。

（4）給水加熱 (冷却) 装置 眝水槽内部へ都市が ス燃焼器を設けて加熱するようにした。冷却するには， 水槽内へ直接に水塊を投入した。そしていずれす定常状 態になるのを待って測定を行った。

（5）温度扣よび湿度の湘定（イ）水温：ノズル 入口拉よび充填層下部の流下口の 2 ケ所にて，検定ず の温度計を用いて㑚定した。（ロ）空気温度および湿度 : 装置の空気入口直前扰よびエリミネータ直後の 2 ケ所 にて検定すみの棒状温度計による乾湿球湿度計にて測定 した。

（6） 水量測定 水量を調節するには, 水圧を变え ることと，使用ノズル数を增诚することにより行った。 また各ノズルについてあらかしめ水量を検定しておき， 水珐扰よび使用したノズルを知って水量を求めた。

（7）空気量測定 空気量を調節するには，送風機 出口に設けてあるタ゚ンパーにより行い，流量の測定はビ ト一管怙よびアネモメータにて風速を測定して求めた。

（8）圧力損失 充填物を通過するときの空究の压
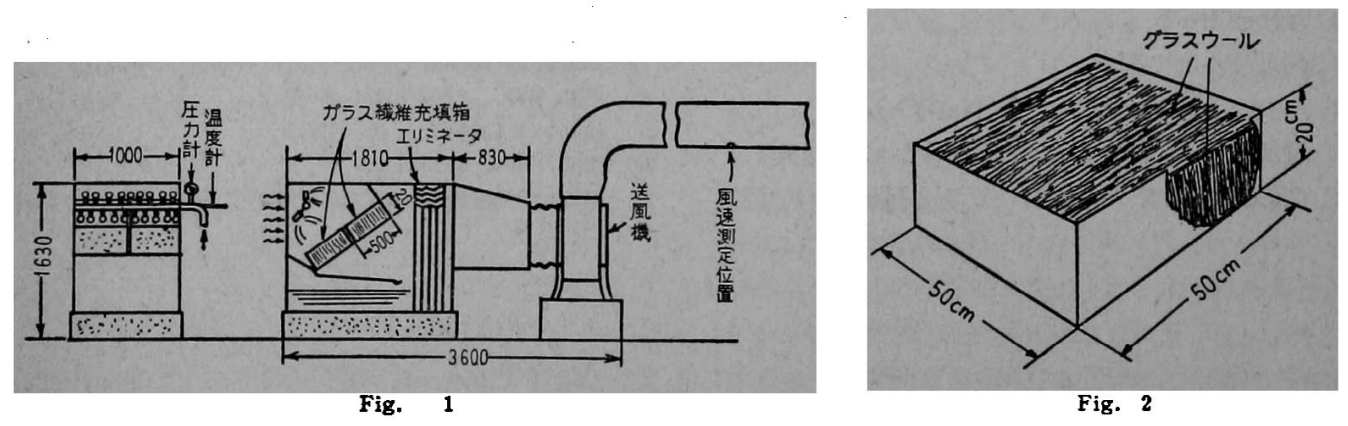

* 昭和 32 年 12 月 28 日受付

** 名古显工莱大学機嘫科

*** 同左学生 
力损失を测るために，充填物へ入る直前とその後におけ る印力よび冉力差を；U字管マノメターにより湘定し た。

\section{3. 衭 号}

$a$ ：熱交換室 $1 \mathrm{~m}^{3}$ 当り空気と水との接触する面積 $\left[\mathrm{m}^{2} / \mathrm{m}^{3}\right], G:$ 空気流量 $[\mathrm{kg} / \mathrm{hr}], H . T . U .:$ 移動単位 長さ [m]， $G^{\prime}$ : 通過断面棈 $1 \mathrm{~m}^{2}$ 当りの空気流量 $[\mathrm{kg} /$

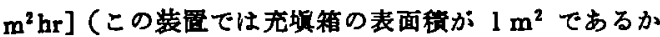
らGと $G^{\prime}$ とは同し数值)， $K_{O G a}$ ：エンタルピ基準エネ ルキ移動俰数 $\left[\mathrm{kcal} / \mathrm{m}^{2} \mathrm{hr}, \mathrm{kcal} / \mathrm{kg}\right] ; \quad L$ : 水の流量 $[\mathrm{kg}$ $/ \mathrm{hr}], L^{\prime}$ : 断面䅡 $1 \mathrm{~m}^{2}$ 当りの水流量 (この装置では $L$ と $L^{\prime}$ と红同し数值) $\left[\mathrm{kg} / \mathrm{m}^{2} \mathrm{hr}\right], L / G$ : 水空気比 $[\mathrm{kg} /$ $\mathrm{kg}], t_{1}, t_{2}\left(t_{1}^{\prime}, t_{2}^{\prime}\right)$ : 空気の入口および出口の乾球 (湿 球) 温度 $\left[{ }^{\circ} \mathrm{C}\right], t_{w 1}, t_{w 2}$ : 水の入口拉よび出口温度 $\left[{ }^{\circ} \mathrm{C}\right]$ $z$ ：装置の有効長さ $[\mathrm{m}](1 \mathrm{~m}$ とする $)$

\section{4. 実験結果}

（1）。使用水温 約 $16.0^{\circ} \mathrm{C} \sim 26.5^{\circ} \mathrm{C}$ (温水), な 与び的 $6.0^{\circ} \mathrm{C} \sim 23.0^{\circ} \mathrm{C}$ (冷水)
（2）水 量
$2,650 \sim 4,500 \mathrm{~kg} / \mathrm{hr}$ の範围
（3）水 压
$0.7 \mathrm{~kg} / \mathrm{cm}^{2}$
(4) 空気量
$2,500 \sim 11,150 \mathrm{~kg} / \mathrm{hr}$ の範囲

以上の実験結果を縓めたすのが Table 1 および Tab-

le 2 である。Table 1 および Table 2 はそれぞれ温水 および命水を噴罯した場合のデータである。

その計算值の 1 つである H.T.U. Кついて，水空気比 $L / G$ を横軸にとってグラフル表わしたのが Fig. 3 であ 子。

温水噴第の場合には測定値が比較的一定しているが， 命水の場合には相当のばらつきがある。しかし全体的俋 見て, 温水の揚合が洽水の場合よりる性能のよいととは はっきりとわかる。

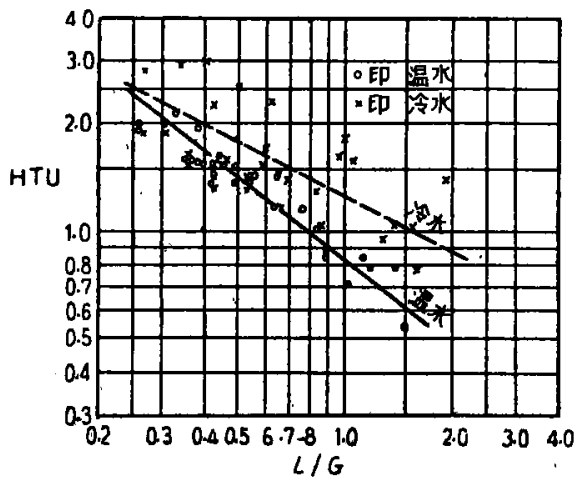

Fig. 3
H.T.U. の值は温水の場合にはだいたい

$$
\text { H.T.U. }=0.83(L / G)^{-4 / 5}
$$

で示すことができ，冷水の場合にはおよそ

$$
\text { H.T.U. }=1.3(L / G)^{-1 / 2}
$$

で示される。

つぎにグラスウール充填層の空気抵抗 $h[\mathrm{mmAq}]$ を Fig. 4 に示す。水を櫴簙したとき $\left(L^{\prime}=4,500 \mathrm{~kg} / \mathrm{hr} \mathrm{m}{ }^{2}\right)$ には、およそ

$$
h=0.8\left(\frac{G^{\prime}}{1,000}\right)^{1.2}
$$

で表わされ，水を噴籍しないとき（ $L=0)$ には，

$$
h=0.7\left(\frac{G^{\prime}}{1,000}\right)^{1.1}
$$

で表わされる。

\section{5. 秸 び}

この装㯰に関する実験は目下続行中であり，本文はそ の1部分であるが，クラスウールを充填物として用いれ ば，熱交換器・物質交換器としての性能が優れて扣り， かなり小型の装置を得ることができると考えられる。

すなわち冷我装㯰に用いたり，空気の増湿用・減湿用 あるいは冷却装置として用いた場合の性能は，良好であ ることが判明した。

なお，空気流に対する充填層抵抗る他の装置に比べて それはと大きいとはいえないし，應芥捕収率る良好であ るし，重量む軽いなどその他の特色を多く持っている。

最後汇，本実験装置は高砂熱学工業株式会社名古屋支 店長服部功氏に寄贈して載いためのであり，グラスウー ルは日本硝子㵶維株式会社から提供して載いたものであ る。ここに深く謝意を表する次第である。

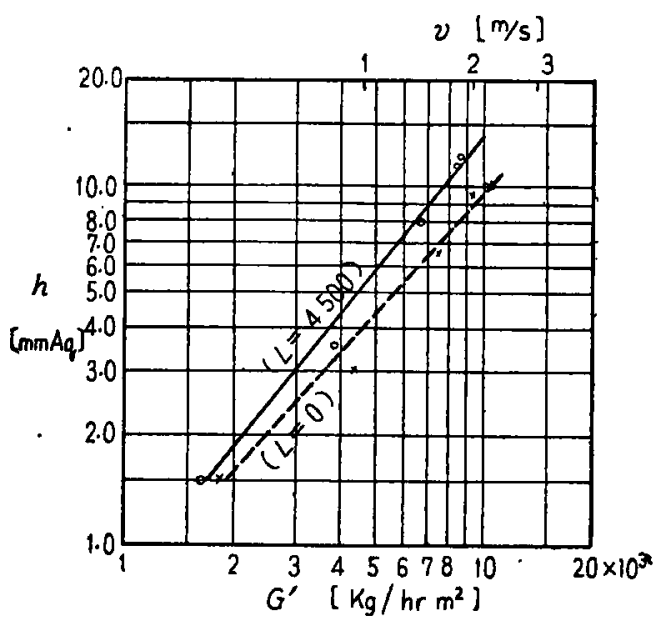

Fig. 1 


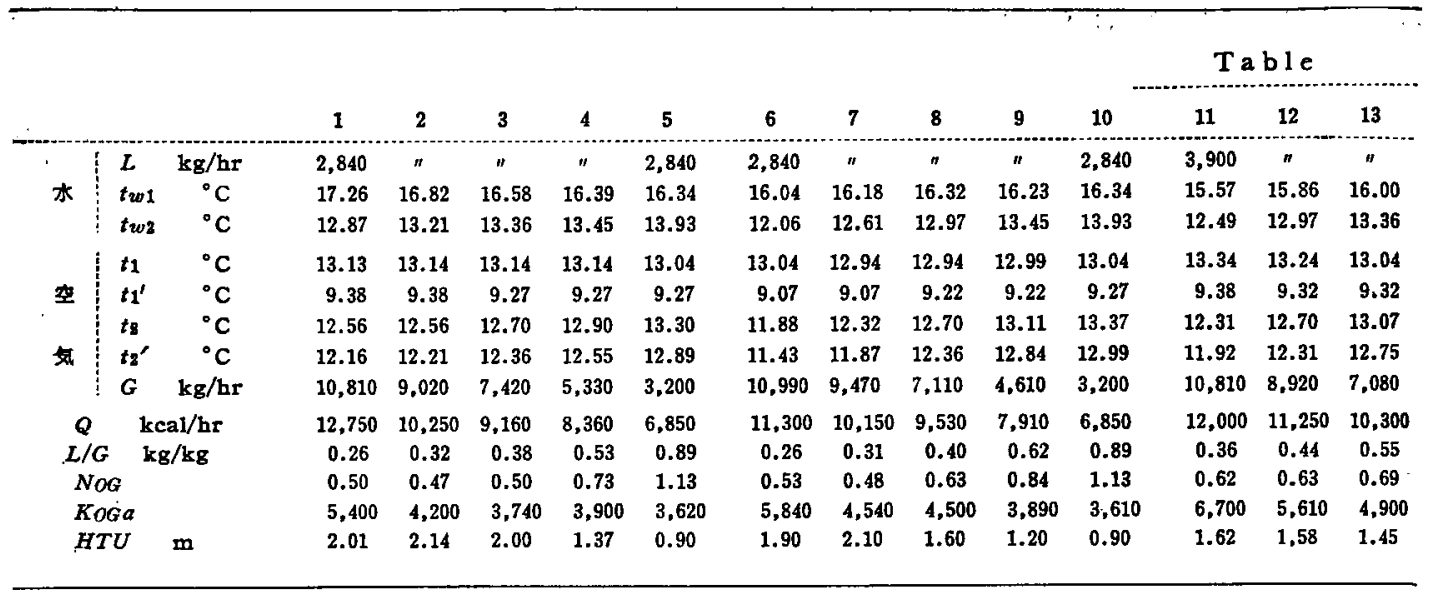

Table

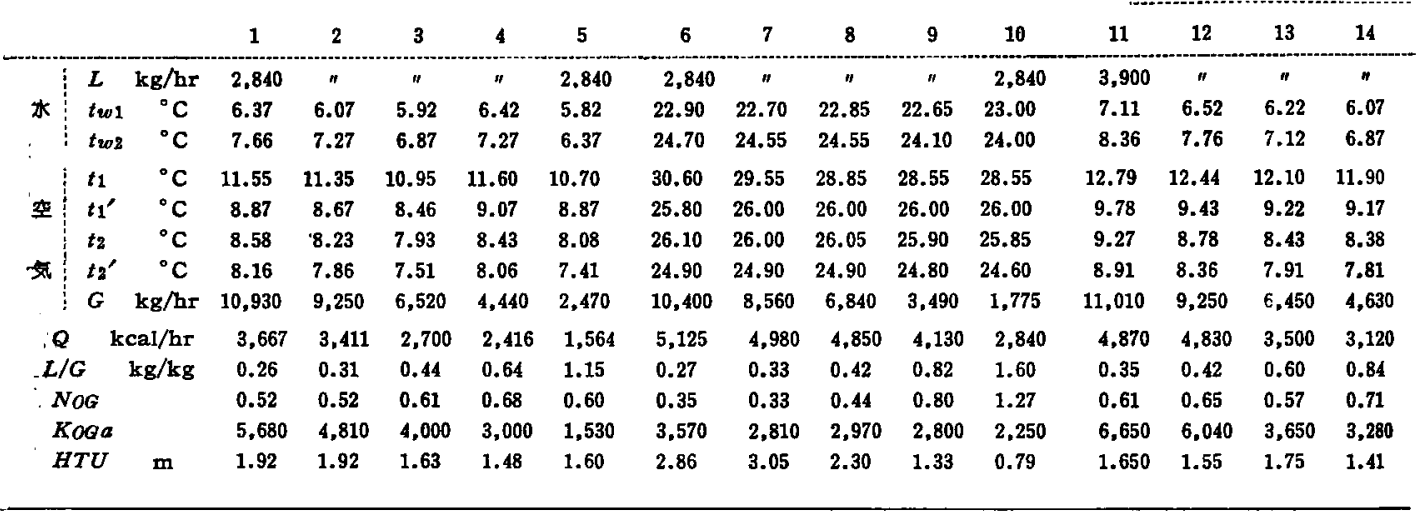

\section{化学機械に関する特許文献}

特許庁田辺義一

\begin{tabular}{|c|c|c|c|c|c|}
\hline 公告番号 & 発明の名意 & 出㰮 $ᄉ$ & 公告番号 & 発明の名称 & 出 \\
\hline $32-5941$ & 薄膜の製造装置 & $\begin{array}{l}\text { ユニオン, カーバイ } \\
\text { ト, コーボレーショ }\end{array}$ & $\begin{array}{l}32-6240 \\
32-6286\end{array}$ & $\begin{array}{l}\text { 篩別选置 } \\
\text { 合成樹脂射出成型 } \\
\text { 機の改良 }\end{array}$ & $\begin{array}{l}\text { 長坂邦彦 } \\
\text { K.K. 松田製作所 }\end{array}$ \\
\hline $\begin{array}{l}32-5943 \\
32-6094\end{array}$ & $\begin{array}{l}\text { 連続式湿式成型装 } \\
\text { 置 } \\
\text { 等王自動調整装置 }\end{array}$ & 住友化学工業 K.K. & $32-6377$ & $\begin{array}{l}\text { 射出型造機械用可 } \\
\text { 槊化シリンダー装 } \\
\text { 置 }\end{array}$ & $\begin{array}{l}\text { マリオ, マシカフェ } \\
\text { リイ }\end{array}$ \\
\hline $\begin{array}{l}32-6115 \\
32-6181\end{array}$ & 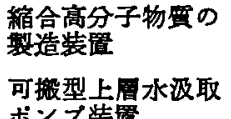 & K.K. 萑原製作所 & $32-6482$ & $\begin{array}{l}\text { 遠心送風機または } \\
\text { ポンプ用の案内䒾 } \\
\text { 植 }\end{array}$ & $\begin{array}{l}\text { フルフレッド, ビュ } \\
\text { ッヒ }\end{array}$ \\
\hline $32-6232$ & 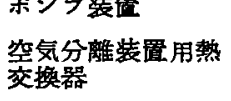 & 日本理化工業 K.K. & $\begin{array}{l}32-6489 \\
32-6491\end{array}$ & $\begin{array}{l}\text { 乾燥機 } \\
" \| "\end{array}$ & 猪飼 兔 \\
\hline $32-6233$ & 鈑皘重式熱交換器 & $\begin{array}{l}\text { フォチエボ ラゲッ } \\
ト, \text { ローぜンブラー } \\
\because, \text { ハテンテル }\end{array}$ & $\begin{array}{l}32-6494 \\
32-6495\end{array}$ & $\begin{array}{l}\text { 湿練機 } \\
\text { 多票型粉末遠心分 } \\
\text { 級機. }\end{array}$ & $\begin{array}{l}\text { 根本三男 } \\
\text { 井伊谷鎆一 }\end{array}$ \\
\hline $32-6234$ & $\begin{array}{l}\text { 粘稠物の熱交澳装 } \\
\text { 置 }\end{array}$ & 条野善次 & $32-6496$ & 粉末粒度分級装膡 & 長坂邦音 \\
\hline $32-6239$ & 笔別装置 & 住友化学工業 K.K. & $32-6498$ & 連続式熱プレス & $\begin{array}{l}\text { ハーキニロク, } \\
\text { ボレーシーシ }\end{array}$ \\
\hline
\end{tabular}




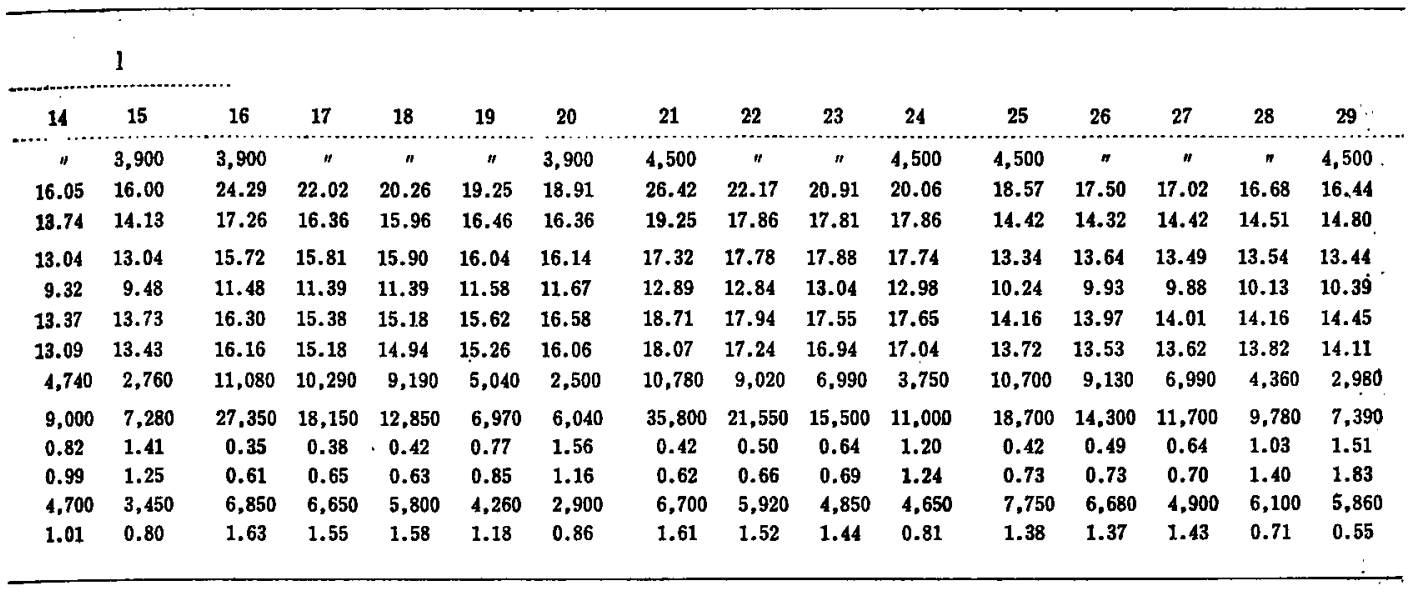

2

\begin{tabular}{|c|c|c|c|c|c|c|c|c|c|c|c|c|c|c|c|}
\hline 15 & 16 & 17 & 18 & 19 & 20 & 21 & 22 & 23 & 24 & 25 & 26 & 27 & 28 & 29 & 30 \\
\hline 3,900 & 3,900 & $"$ & " & $"$ & 3,900 & 4,500 & $"$ & $"$ & $n$ & 4,500 & 4,500 & " & " & " & 4,500 \\
\hline 5.77 & 7.36 & 7.56 & 7.36 & 7.46 & 7.76 & 6.67 & 6.57 & 6.57 & 6.57 & 6.47 & 8.36 & 7.91 & 7.66 & 7.56 & 7.51 \\
\hline 6.47 & 8.56 & 8.61 & 8.26 & 8.26 & 8.26 & 7.22 & 7.12 & 7.07 & 6.97 & 6.77 & 9.16 & 8.76 & 8.46 & 8.16 & $7.96^{\circ}$ \\
\hline 11.65 & 12.84 & 12.69 & 12.79 & 12.79 & 12.59 & 12.69 & 12.74 & 12.79 & 12.69 & 12.74 & 12.64 & 12.44 & 12.29 & 12.05 & 11.75 \\
\hline 8.97 & 9.88 & 9.93 & 10.08 & 10.08 & 10.19 & 8.57 & 8.57 & 8.62 & 8.72 & 8.87 & 10.08 & 10.03 & 9.98 & 9.98 & 9.98 \\
\hline 8.53 & 9.52 & 9.57 & 9.47 & 9.37 & 9.42 & 8.04 & 7.99 & 7.99 & 8.09 & 8.63 & 9.91 & 9.57 & 9.32 & 9.17 & 9.12 \\
\hline 7.81 & 9.11 & 9.21 & 9.11 & 9.01 & 9.01 & 7.51 & 7.51 & 7.51 & 7.51 & 7.66 & 9.55 & 9.21 & 8.91 & 8.76 & 8.91 \\
\hline 3,070 & 11,140 & 9,260 & 6,610 , & 4,610 & 2,810 & 10,980 & 9,120 & 7,320 & 4,440 & 2,360 & 10,750 & 8,740 & 7,100 & 4,780 & 3,030 \\
\hline 2,720 & 4,680 & 4,090 & 3,500 & 3,120 & 1,950 & 2,480 & 2,480 & 2,250 & 1,800 & 1,350 & 3.600 & 3,826 & 3,600 & 2,700 & 2,025 \\
\hline 1.27 & 0.35 & 0.42 & 0.59 & 0.85 & 1.39 & 0.41 & 0.50 & 0.62 & 1.01 & 1.91 & 0.42 & 0.52 & 0.66 & 0,98 & 1.55 \\
\hline 1.02 & 0.63 & 0.74 & 0.64 & 0.97 & 0.92 & 0.36 & 0.41 & 0.44 & 0.53 & 0.67 & 0.72 & 0.74 & 0.84 & 0.80 & 0.97 \\
\hline 3,140 & 7,050 & 6,870 & 4,260 & 4,450 & 2,595 & 3,900 & 3,760 & 3,190 & 2.350 & 1,580 & 7,460 & 6,480 & 5,990 & 3,830 & 2,950 \\
\hline 0.98 & 1.58 & 1.35 & 1.55 & 1.04 & 1.08 & 2.81 & 2.42 & 2.30 & 1.89 & 1.49 & 1.40 & 1.35 & 1.19 & 1.25 & $1.08^{\circ}$ \\
\hline
\end{tabular}

\section{化学機械に関する特許文献}

特許庁田辺義一

\begin{tabular}{|c|c|c|c|c|c|}
\hline 公告番号 & 発明の名剓 & 出 1 & 公告番号 & 発明の名采 & 出 $人$ \\
\hline $32-6519$ & 粉末材料送秴装贯 & インフ & $32-7046$ & 連続粘度湘定装圈 & K.K. 島津製作新 \\
\hline $32-6694$ & $\begin{array}{l}\text { 連続式真空渱過装 } \\
\text { 直 }\end{array}$ & 前田千代松 & $32-7087$ & $\begin{array}{l}\text { 身出型成機械用加 } \\
\text { 熱シリンター装埴 } \\
\text { の改良 }\end{array}$ & $\begin{array}{l}\text { マリオ, マッカ, > } \\
\text { エリイ }\end{array}$ \\
\hline $32-6695$ & 眽動式王力涯過法 & 住友化学工業 K.K. & $32-7196$ & 徽粒子分粐装膡 & 不二機械工業 K.K. \\
\hline $32-6696$ & 滤過装置 & $\begin{array}{l}\text { ヘンリー, ジョンッ } \\
\text { ン・ヘーシー }\end{array}$ & $32-7280$ & 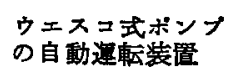 & 高砂鉄工 K.K. \\
\hline $32-6729$ & 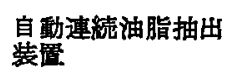 & 牧実 & $32-7281$ & $\begin{array}{l}\text { 滑動ブランジャー } \\
\text { 機棈 }\end{array}$ & $\begin{array}{l}\text { ソシェテ, バール } \\
\text { シオネ, キャンビ, }\end{array}$ \\
\hline $32-6736$ & 自動圷擦成形装置 & 上滝丁藏 & & & $\begin{array}{l}\hat{1} \text { ドラウリン, } \\
\text { こニ }\end{array}$ \\
\hline $\begin{array}{l}32-6842 \\
32-6943\end{array}$ & $\begin{array}{l}\text { ローラー加熱法置 } \\
\text { 乾燥機 }\end{array}$ & $\begin{array}{l}\text { 三菱レイョン K.K. } \\
\text { 真壂宫太郎 }\end{array}$ & 282 & 歯車ポンフ & K.K. 島津製作所 \\
\hline $32-6945$ & 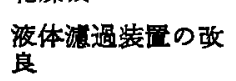 & $\begin{array}{l}\text { レシェ,フンド, } \\
\text { ルネ,フクチボラダ }\end{array}$ & $32-7283$ & $\begin{array}{l}\text { 排気ガスターボ送 } \\
\text { 風機 }\end{array}$ & 三井造船 K.K： \\
\hline $32-6946$ & 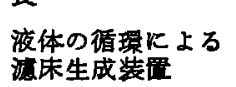 & 楖下相三郎 & $\begin{array}{l}32-7292 \\
32-7293\end{array}$ & $\begin{array}{l}\text { 混合機 } \\
\text { 濾過装置 }\end{array}$ & $\begin{array}{l}\text { 狩野春一 外 } 2 . \\
\text { 三浦 貢 }\end{array}$ \\
\hline
\end{tabular}

